\title{
Autoantibodies in childhood connective tissue diseases and in normal children
}

\author{
K. M. GOEL, R. A. SHANKS, K. WHALEY, MARY MASON, and R. N. M. MacSWEEN \\ From the Royal Hospital for Sick Children, Glasgow; University of Glasgow, Department of Pathology, \\ Western Infirmary; and Regional Immunopathology Laboratory, Centre for Rheumatic Diseases, Baird Street, \\ Glasgow
}

\begin{abstract}
Goel, K. M., Shanks, R. A., Whaley, K., Mason, M., and MacSween, R. N. M. (1975). Archives of Disease in Childhood, 50, 419. Autoantibodies in childhood connective tissue diseases and in normal children. The prevalence of nine serum autoantibodies has been studied in 117 children with various connective tissue disorders and in 134 normal controls. In juvenile rheumatoid arthritis rheumatoid factor was present in 5\%, and antinuclear factor in $4 \%$, compared with an incidence of $4 \%$ and $0 \%$ respectively in controls. In Henoch-Schönlein purpura there was little evidence of associated autoimmune disorder. Gastric parietal cell and thyroid microsomal antibodies were found in $9 \%$ and $10 \%$ of our control population, but the significance of this is not clear. It is concluded that in children the presence or absence of autoantibodies as diagnostic criteria should be interpreted with the greatest caution.
\end{abstract}

In contrast to the many reports of the incidence and significance of serum autoantibodies in connective tissue diseases in adults, there have been relatively few reports of their incidence in children with these diseases and even fewer reports of their incidence in normal children (Alexander, Bremner, and Duthie, 1960; Beck, 1961; Doniach, Nilsson, and Roitt, 1965; Kornreich, Drexler, and Hanson, 1966; Bluestone et al., 1970; Petty, Cassidy, and Sullivan, 1973). In the present study sera from 117 patients who had suffered from connective tissue diseases in childhood and sera from 134 controls have been screened for the prevalence of nine circulating organ- or nonorgan-specific autoantibodies.

\section{Materials and methods}

\section{Patient groups.}

Juvenile rheumatoid arthritis (JRA). There were 54 patients (34 female, 20 male) with JRA selected according to the criteria of Ansell and Bywaters (1959). Age at onset of disease varied from 9 months to 12 years with a mean of $6 \frac{1}{2}$ years, the onset being polyarticular in 49 and monarticular in 5 . At the time of study their ages ranged from 5 to 37 years (mean 16 years). The disease was in clinical remission in 46 while $8 \mathrm{had}$ active rheumatoid disease, all 8 having had polyarticular disease from the onset.

Received 15 November 1974.
Henoch-Schönlein purpura (HSP). 52 children (35 male, 17 female) had the typical clinical features of HSP. Age at onset of disease ranged from 9 months to 11 years (mean 6 years). At the time of study their ages ranged from 3 to 15 years (mean 8 years); 48 were in clinical remission, while 4 had evidence of continuing renal disease.

Other connective tissue disease $(C T)$. There were 5 children with scleroderma (ages at onset $1 \frac{3}{4}$ years, 2 years, 43 years, 9 years, 11 years). At the time of study the disease was quiescent in 2 and slowly progressive in the others. 4 children had systemic lupus erythematosus (SLE), in one of whom the disease had been induced by ethosuximide. 2 of these patients developed renal involvement, one with a fatal outcome. In the other 2 the disease was quiescent at the time of study. 2 patients with dermatomyositis completed the CT group and both were in remission at the time of study.

Control group. Sera were obtained from venous blood in 112 healthy children (age range 0 to 15 years and from 22 young adults (age range 16 to 37 years). The patients had attended hospital because of minor trauma or for simple surgical procedures (e.g. minor lacerations, simple fractures, incision of abscesses, and finger tip injuries), and in the children blood was withdrawn primarily for other investigations. In none of these patients was there any personal or family history to suggest a connective tissue disorder.

Serological techniques.

Antinuclear factor $(A N F)$. An indirect immuno- 
fluorescence technique was used with rat liver as substrate (Beck, 1961). All sera were tested at a dilution of 1 in 16, but positive sera were then titrated in quadrupling dilution till an endpoint of nuclear fluorescence was obtained. The pattern of nuclear staining (homogeneous, nucleolar, speckled, or membranous) was also recorded.

Rheumatoid factor. Sera were screened undiluted using a slide agglutination technique (Rheumaton, Warner Laboratories Ltd.) and titration of positive sera was performed using the $R_{3}$ Latex kit (Warner Laboratories Ltd.).

Smooth muscle antibody was shown by an indirect immunofluorescence technique using rat stomach as substrate (Johnson, Holborow, and Glynn, 1965). Sera were tested at a dilution of 1 in 16 , and results recorded as positive or negative.

Antimitochondrial or $M$-antibody was shown by an indirect immunofluorescence technique using rat kidney as substrate (Goudie, MacSween, and Goldberg, 1966). Sera were tested at a dilution of 1 in 16, and positive sera were titrated in doubling dilution and endpoint of fluorescent staining was found.

Thyroglobulin antibody was detected by tanned red cell passive haemagglutination technique (Fulthorpe et al., 1961), the sera being screened at 1 in 16 dilution and positive sera being titrated in quadrupling dilution to an end-point of red cell agglutination.

Thyroid microsomal antibody was tested using an indirect immunofluorescence technique with toxic human thyroid gland as substrate and the serum diluted 1 in 4 (Holborow et al., 1959).

Gastric parietal cell antibody was tested by indirect immunofluorescence using human mucosa as substrate with undiluted serum (Adams et al., 1964).

Salivary duct antibody was detected by an indirect immunofluorescence technique using human submandibular gland as substrate with undiluted serum (MacSween et al., 1967).

Adrenal cortex antibody was tested by an indirect immunofluorescence technique using human adrenal gland as substrate with the serum undiluted (Goudie et al., 1969).

Anti-DNA antibodies were tested by a modification of the Farr techniques (Webb, Whaley, and Lee, 1974).

\section{Results}

The results are summarized in Tables I and II. $M$-antibody and adrenal cortex antibody were not detected in either the patients or the normal controls. In only one instance (a patient with JRA) was antithyroglobulin antibody found (titre 1/16). Salivary duct antibody was found in 4 normal controls but in only one was the result strongly positive.

Rheumatoid factor. In the control population a positive rheumaton test was recorded in 5 out

TABLE I

Incidence of autoantibodies in patients and controls

\begin{tabular}{|c|c|c|c|c|c|c|c|}
\hline Disease & $\begin{array}{l}\text { No. of } \\
\text { patients }\end{array}$ & $\begin{array}{l}\text { Antinuclear } \\
\text { factor }\end{array}$ & $\begin{array}{l}\text { Rheumaton } \\
\text { test }\end{array}$ & $\mathbf{R}_{\mathbf{3}}$ titre & $\begin{array}{l}\text { Smooth } \\
\text { muscle } \\
\text { antibody }\end{array}$ & $\begin{array}{l}\text { Gastric } \\
\text { parietal cell } \\
\text { antibody }\end{array}$ & $\begin{array}{l}\text { Thyroid } \\
\text { microsomal } \\
\text { antibody }\end{array}$ \\
\hline $\begin{array}{l}\text { JRA (54) } \\
\text { Active } \\
\text { Quiescent }\end{array}$ & $\begin{array}{r}8 \\
46\end{array}$ & 0 & $\begin{array}{l}3(1,+; \\
2,++) \\
0\end{array}$ & $\begin{array}{l}2(1 / 64 \\
1 / 128) \\
0\end{array}$ & $\begin{array}{l}0 \\
0\end{array}$ & $\begin{array}{l}1(W+) \\
0\end{array}$ & $\begin{array}{l}0 \\
0\end{array}$ \\
\hline $\begin{array}{l}\text { HSP (52) } \\
\text { Recovered } \\
\text { With chronic nephritis }\end{array}$ & $\begin{array}{r}48 \\
4\end{array}$ & $\begin{array}{l}\mathbf{0} \\
\mathbf{0}\end{array}$ & $\begin{array}{l}0 \\
1(++)\end{array}$ & $\begin{array}{l}\mathbf{0} \\
0\end{array}$ & $\begin{array}{l}2(\mathbb{W}+) \\
0\end{array}$ & $\begin{array}{l}2(W+) \\
0\end{array}$ & $\begin{array}{l}\mathbf{0} \\
\mathbf{0}\end{array}$ \\
\hline SLE (4) & 4 & 4 & $1(++)$ & $1(1 / 16)$ & 0 & 0 & 0 \\
\hline $\begin{array}{l}\text { Scleroderma (5) } \\
\text { Slowly progressive } \\
\text { Quiescent }\end{array}$ & $\begin{array}{l}3 \\
2\end{array}$ & $\begin{array}{l}3 \\
0\end{array}$ & $\begin{array}{l}\mathbf{0} \\
\mathbf{0}\end{array}$ & $\begin{array}{l}\mathbf{0} \\
\mathbf{0}\end{array}$ & $\begin{array}{l}\mathbf{0} \\
0\end{array}$ & $\begin{array}{l}\mathbf{0} \\
\mathbf{0}\end{array}$ & $\begin{array}{l}\mathbf{0} \\
\mathbf{0}\end{array}$ \\
\hline $\begin{array}{l}\text { Dermatomyositis (2) } \\
\text { Quiescent }\end{array}$ & 2 & 0 & 0 & 0 & $1(\mathbb{W}+)$ & $1(++)$ & 0 \\
\hline Control group & 134 & 0 & $5(++)$ & $\begin{array}{l}2(1 / 16 \\
1 / 32)\end{array}$ & $\begin{array}{l}5(4, w+; \\
1,++)\end{array}$ & $\begin{array}{l}12(7, w+; \\
3,+; \\
2,++)\end{array}$ & $\begin{array}{l}14(13,+; \\
1,++)\end{array}$ \\
\hline Total & 251 & 9 & 10 & 5 & 8 & 16 & 14 \\
\hline
\end{tabular}

$\mathbb{W}+$, weakly positive; + , positive; ++ , strongly positive. No. in parenthesis $=$ No. of patients. 
TABLE II

Details of 9 patients with positive antinuclear factors

\begin{tabular}{|c|c|c|c|c|c|c|c|c|}
\hline Disease & $\begin{array}{c}\text { No. of } \\
\text { patients (9) }\end{array}$ & Age (yr) & Sex & ANF titre & $\begin{array}{c}\text { Nuclear } \\
\text { fluorescence }\end{array}$ & $\begin{array}{l}\text { DNA binding } \\
\text { capacity (\%) }\end{array}$ & LE cells & Current status \\
\hline JRA & $2(4)^{\star}$ & $\begin{array}{l}2 \frac{1}{2} \\
4 \frac{3}{4}\end{array}$ & $\begin{array}{l}\mathbf{F} \\
\mathbf{M}\end{array}$ & $\begin{array}{l}1 / 256 \\
1 / 16\end{array}$ & $\underset{\mathbf{H}}{\mathrm{H}, \mathrm{N}}$ & $\begin{array}{l}0 \\
0\end{array}$ & $\begin{array}{l}\text {-ve } \\
\text {-ve }\end{array}$ & $\begin{array}{l}\text { Arthritis active } \\
\text { Arthritis active }\end{array}$ \\
\hline Scleroderma & $3(60)$ & $\begin{array}{l}2 \\
9 \\
5\end{array}$ & $\begin{array}{l}\mathbf{F} \\
\mathbf{M} \\
\mathbf{F}\end{array}$ & $\begin{array}{l}1 / 256 \\
1 / 1000 \\
1 / 1000\end{array}$ & $\begin{array}{c}\mathbf{H} \\
\mathbf{H} \\
\mathbf{H}, \mathbf{S}\end{array}$ & $\begin{array}{l}0 \\
0 \\
0\end{array}$ & $\begin{array}{l}\text { +ve } \\
\text {-ve } \\
\text { +ve }\end{array}$ & $\begin{array}{l}\text { Slowly progressive } \\
\text { Slowly progressive } \\
\text { Slowly progressive }\end{array}$ \\
\hline SLE & $4(100)$ & $\begin{array}{r}11 \\
9 \\
12 \\
8\end{array}$ & $\begin{array}{l}\mathbf{F} \\
\mathbf{F} \\
\mathbf{F} \\
\mathbf{M}\end{array}$ & $\begin{array}{l}1 / 256 \\
1 / 16 \\
1 / 256 \\
1 / 256 t\end{array}$ & $\begin{array}{c}\mathrm{H}, \mathrm{N} \\
\mathrm{H} \\
\mathrm{H}, \mathrm{S} \\
\mathrm{H}, \mathrm{N}\end{array}$ & $\begin{array}{l}79 \\
29 \\
65 \\
29\end{array}$ & $\begin{array}{l}\text { +ve } \\
+ \text { ve } \\
+ \text { ve } \\
+ \text { ve }\end{array}$ & $\begin{array}{l}\text { In remission (lupus } \\
\text { nephritis) } \\
\text { Lost to follow up } \\
\text { Died of renal failure } \\
\text { Alive and well }\end{array}$ \\
\hline
\end{tabular}

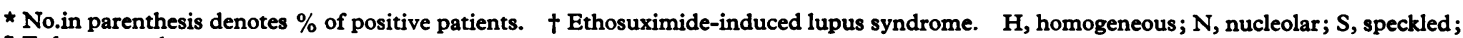
LE, lupus erythematosus.

of $134(4 \%)$ but in only 2 of these was the $R_{3}$ test positive, to a titre of $1 / 16$ and $1 / 32$, respectively. In the JRA group a positive rheumaton test was found in 3 out of $54(5 \%)$, and in 2 of these who had active disease positive $R_{3}$ titres of $1 / 64$ and $1 / 128$ were recorded. One of the 52 patients with HSP gave a positive rheumaton test, but was negative on $R_{3}$ titration, and 1 of 4 SLE patients was positive in both, the $R_{3}$ titre being weakly positive at 1/16: in neither instance can the result be regarded as of pathological significance.

Antinuclear factor. This was not shown in any of the controls, but was found in 2 of 54 JRA patients, 3 of 5 patients with scleroderma, and in all 4 patients with SLE. Details of these patients are presented in Table II. In 2 of the children with SLE, one being ethosuximide induced, ANF was no longer demonstrable in the serum on followup and in both patients this disease became clinically quiescent.

Anti-DNA antibodies were found in 4 out of 9 patients with positive ANF tests. Over $30 \%$ DNA binding capacity was taken to be significant. Increased binding of DNA was found in 2 of the SLE group, both of whom had clinical evidence of renal involvement.

Gastric parietal cell antibody. In the patients 4 sera were positive, 1 in JRA, 2 in HSP, and 1 in dermatomyositis, and of these only the latter gave strong positive staining. In contrast in the control group 12 sera were positive, an incidence of $8.9 \%$ positive. Of these, 8 occurred in children under 10 years, 5 weakly positive, and of the 4 positives in the 11- to 16-year age group 2 were weakly positive.
Thyroid microsomal antibody. This was not shown in any of the patient groups. However, it was shown in 14 of $134(10 \%)$ of the controls, 13 of whom were under 10 years, and in all of these sera a weakly positive staining reaction was recorded. The remaining case producing a strongly positive staining pattern was from a 16 year old.

Smooth muscle antibody. This was found in 2 of the 52 patients with HSP and in 1 of 2 patients with dermatomyositis, all being only weakly positive. Five positive results were obtained in the controls, all 5 being under 10 years old. In only one instance, however, was the result strongly positive.

\section{Discussion}

Few studies have been reported of the frequency of autoantibodies in diseased or healthy children (Doniach et al., 1965; Kornreich et al., 1966; Petty et al., 1973). In the present work we have studied a series of autoantibodies in children with selected connective tissue diseases, and in a large control group with minor ailments, in whom there was no reason to suspect any underlying major disease process and, in particular, no evidence of any disease of possible immunological aetiology. With the exception of gastric parietal cell antibody and thyroid microsomal antibody, autoantibodies were infrequently found in the children studied. Antinuclear factor was not found in any of the control population. The present finding of ANF in 2 out of $54(4 \%)$ of our JRA patients compares with previous reports ranging from 4-55\% (Weir, Holborow, and Johnson, 1961 ; Barnett et al., 1965; Bluestone et al., 1970). In part these differences in incidence probably reflect differences in the 
degree of activity of the disease at the time of serological examination, and differences in the technique of examination. Both of our JRA patients with ANF had evidence of a continuing disease process consistent with previous reports that the presence of this antibody is associated with more severe progressive form of the disease. Petty and others (1973) found ANF in 38.5\% of their patients with JRA compared with only $3 \%$ of their controls, the sera being examined undiluted. In our laboratory we have consistently screened for ANF at a serum dilution of $1 / 16$, and at this titre or greater ANF is demonstrable in $12-14 \%$ of normal adults. As in most other studies, ANF was found in all patients with SLE (4) and was found in 3 of the 5 patients with scleroderma. In the latter group its presence was associated with slow progression of the disease process. In 2 of the 4 SLE patients significant DNA binding was shown by the Farr technique and both of these had developed evidence of renal involvement with a fatal outcome in one.

Rheumatoid factor was found to be no more frequent in our JRA groups than in the controls. In a previous study we have shown that those JRA patients with rheumatoid factor may have a more serious prognosis (Goel and Shanks, 1974).

Smooth muscle and salivary duct antibodies were found in 8 ( 5 controls) and 4 (all controls) children, respectively. There was no evidence of liver or salivary gland dysfunction in these children, and the significance of this finding is not clear.

A surprising finding was the high incidence of (mainly weakly) positive gastric parietal cell (9\%) and thyroid microsomal (10\%) antibody in our control population. It is of interest that in a previous study in this region (R. N. M. MacSween, and R. B. Goudie, unpublished, 1967) these antibodies were found in approximately similar proportions in another population of normal young children. Doniach et al. (1965) found gastric parietal cell and thyroid microsomal antibodies in 4 and $2 \%$ of juvenile controls, respectively. It is of interest that 10 of the control children had more than one antibody present: parietal cell and thyroid microsomal 4, parietal cell and smooth muscle 2, thyroid microsomal and salivary duct 2 , thyroid microsomal and smooth muscle 1 . It is also noteworthy that if all the positive results for these 4 autoantibodies are examined on the basis of age distribution, 19 occurred in the 0 - to 5-year age group, 11 in the $6-10,1$ in the $11-15$, and 4 in the $16+$ years group, suggesting that their occurrence is possibly a transient phenomenon. The exact significance of these observations in our control population is not clear, but it seems that the possibility of a serological follow-up study on this small group of children should perhaps be undertaken.

The overall picture of the incidence of autoantibodies revealed in this study suggests that except for SLE and perhaps scleroderma there is little difference between those children who belong to the admittedly heterogeneous group of so-called connective tissue diseases and the normal controls from the same area.

We conclude that these autoantibody tests can not be used in childhood as reliable diagnostic criteria.

In our 52 patients with Henoch-Schönlein syndrome there was no evidence of any associated autoimmune phenomena. The multisystem involvement in this syndrome is more suggestive of an immune-complex disease pattern, and it is doubtful whether it should be included as one of the autoimmune connective tissue diseases.

We are grateful to our colleagues for allowing us to study patients under their care, and to the adult volunteers for giving their blood for this project.

\section{REFERENCES}

Adams, J. F., Glen, A. I. M., Kennedy, E. H., Mackenzie, I. L., Morrow, J. M., Anderson, J. R., Gray, K. G., and Middleton, D. G. (1964). The histological and secretory changes in the stomach in patients with autoimmunity to gastric parietal cells. Lancet, 1, 401.

Alexander, W. R. M., Bremner, J. M., and Duthie, J. J. R. (1960). Incidence of the antinuclear factor in human sera. Annals of the Rheumatic Diseases, 19, 338.

Ansell, B. M., and Bywaters, E. G. L. (1959). Prognosis in Still's disease. Bulletin on the Rheumatic Diseases, 9, 189.

Barnett, E. V., North, A. F., Condemi, J. J., Jacox, R. F., and Vaughan, J. H. (1965). Antinuclear factors in systemic lupus erythematosus and rheumatoid arthritis. Annals of Internal Medicine, 63, 100.

Beck, J. S. (1961). Variations in the morphological patterns of 'autoimmune' nuclear fluorescence. Lancet, 1, 1203.

Bluestone, R., Goldberg, L. S., Katz, R. M., Marchesano, J. M., and Calabro, J. J. (1970). Juvenile rheumatoid arthritis: a serologic survey of 200 consecutive patients. Fournal of Pediatrics, 77, 98.

Doniach, D., Nilsson, L. R., and Roitt, I. M. (1965). Autoimmune thyroiditis in children and adolescents, Acta Paediatrica Scandinavica, 54, 260.

Fulthorpe, A. J., Roitt, I. M., Doniach, D., and Couchman, K. (1961). A stable sheep cell preparation for detecting thyroglobulin auto-antibodies and its clinical applications. fournal of Clinical Pathology, 14, 654.

Goel, K. M., and Shanks, R. A. (1974). Follow-up study of 100 cases of juvenile rheumatoid arthritis. Annals of the Rheumatic Diseases, 33, 25.

Goudie, R. B., MacSween, R. N. M., and Goldberg, D. M. (1966). Serological and histological diagnosis of primary biliary cirrhosis. Fournal of Clinical Pathology, 19, 527.

Goudie, R. B., Stuart-Smith, D. A., Boyle, I. T., and Ferguson, A. (1969). Serological diagnosis of idiopathic Addison's disease in patients on prolonged prednisolone therapy for steatorrhoea. Lancet, 1, 186. 
Holborow, E. J., Brown, P. C., Roitt, I. M., and Doniach, D. (1959). Cytoplasmic localization of 'complement-fixing' autoantigen in human thyroid epithelium. British fournal of Experimental Pathology, 40, 583.

Johnson, G. D., Holborow, E. J., and Glynn, L. E., (1965). Antibody to smooth muscle in patients with liver disease. Lancet, 2,878 .

Kornreich, H. K., Drexler, E., and Hanson, V. (1966). Antinuclear factors in childhood rheumatic diseases. Fournal of Pediatrics, 69, 1039.

MacSween, R. N. M., Goudie, R. B., Anderson, J. R., Armstrong, E., Murray, M. A., Mason, D. K., Jasani, M. K., Boyle, J. A., Buchanan, W. W., and Williamson, J. (1967). Occurrence of antibody to salivary duct epithelium in Sjögren's disease, rheumatoid arthritis, and other arthritides. Annals of the Rheumatic Diseases, 26, 402.
Petty, R. E., Cassidy, J. T., and Sullivan, D. B. (1973). Clinical correlates of antinuclear antibodies in juvenile rheumatoid arthritis. Fournal of Pediatrics, 83, 386.

Webb, J., Whaley, K., and Lee, P. (1974). Clinical significance of native DNA antibodies in systemic lupus erythematosus and other connective tissue diseases. Scottish Medical fournal, 19, 171.

Weir, D. M., Holborow, E. J., and Johnson, G. D. (1961). A clinical study of serum antinuclear factor. British Medical fournal, 1, 933.

Correspondence to Dr. K. M. Goel, Royal Hospital for Sick Children, Glasgow G3 8SJ. 